\title{
PREFERENSI KONSUMEN PRODUK KEFIR SUSU KAMBING DI MALANG
}

\author{
Zaenal Fanani \\ Universitas Brawijaya Malang \\ prof_zaenalfanani@yahoo.co.id \\ Imam Tohari \\ Universitas Brawijaya Malang
}

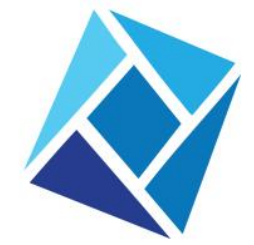

Jurnal Nusantara

Aplikasi Manajemen Bisnis

http://ojs.unpkediri.ac.id/index. $\mathrm{php} /$ manajemen/index

E-ISSN : 2528-0929

P-ISSN : 2549 - 5291

Diterima: 08 Februari 2018

Revisi : 26 Maret 2018

Disetujui: 18 April 2018

httpsdoi.org10.29407nusamba.

v3i1.12029

\section{Abstract}

This study aims to analyze the factors that influence the purchase decisions of goat milk kefir and analyze the factors that affect the consumer preferences of goat milk kefir. The material used in this research is consumer of goat milk kefir in Malang Regency. Population in this research is all consumer of goat milk kefir in Malang Regency, while target population is consumer of goat milk kefir in East Java. Sampling is done through 3 stages namely the determination of the sample location is done by Purposive Sampling method. Sampling of respondents was done by accidental sampling of 100-200 people. Research data consist of primary data and secondary data. The research instrument used questionnaires with Likert scale. The contribution of variables that influence purchasing decisions and consumer preferences is tested using multiple linear regression, mathematically $Y=a+$ $\beta 1 X 1+\beta 2 X 2+\beta 3 X 3+\beta 4 X 4+\ldots \ldots+\beta n X n+e$. The result of this research is that factors influencing decision making of goat milk kefir are security guarantee factor, physiological satisfaction, sociological satisfaction, selfesteem satisfaction, and actualization with multiple regression equation $Y=$ $0,629+0,056 X 1+0,159 X 2+0,080 X 3-0,053 X 4+0.048 X 5$. Factors influencing consumer preference are halal factor, ingredient, nutritional value, health, habit, and nature factor factor with multiple regression equation $Y=$ $1.857+0.065 X 1+0.082 X 2+0.112 X 3+0.123 X 4+0.067 X 5+0,045$

Kata Kunci: Consumer Preferences, Kefir

\section{Abstrak}

Penelitian ini bertujuan untuk menganalisis faktor-faktor yang berpengaruh terhadap keputusan pembelian kefir susu kambing dan menganalisis faktor-faktor yang berpengaruh terhadap preferensi konsumen kefir susu kambing. Materi yang digunakan dalam penelitian ini adalah konsumen kefir susu kambing yang ada di Kabupaten Malang. Populasi dalam penelitian ini adalah seluruh konsumen kefir susu kambing di Kabupaten Malang, sedangkan populasi targetnya adalah konsumen kefir susu kambing di Jawa Timur. Pengambilan sampel dilakukan melalui 3 tahap yaitu penentuan sampel lokasi dilakukan dengan metode Purposive Sampling. Pengambilan sampel responden dilakukan secara aksidental Sampling sebanyak 100-200 orang. Data penelitian terdiri dari data primer dan data sekunder. Instrumen penelitian menggunakan kuisioner dengan skala Likert. Sumbangan variabel yang mempengaruhi keputusan pembelian dan preferensi konsumen diuji menggunakan regresi linier berganda, secara matematis adalah $Y=a+\beta_{1} X_{1}+$ $\beta_{2} X_{2}+\beta_{3} X_{3}+\beta_{4} X_{4}+\ldots \ldots+\beta_{n} X_{n}+e$. Hasil penelitian bahwa Faktor-faktor yang berpengaruh terhadap pengambilan keputusan pembelian kefir susu kambing adalah faktor jaminan keamanan, kepuasan fisiologis, kepuasan sosiologis, kepuasan harga diri, dan aktualisasi dengan persamaan regresi berganda $\mathrm{Y}=0,629+0,056 \mathrm{X}_{1}+0,159 \mathrm{X}_{2}+0,080 \mathrm{X}_{3}-0,053 \mathrm{X}_{4}+0,048 \mathrm{X}_{5}$. Faktor-faktor yang berpengaruh terhadap preferensi konsumen adalah faktor halal, ingredient, nilai gizi, kesehatan, kebiasaan, dan faktor nature produc dengan persamaan regresi berganda $\mathrm{Y}=1,857+0,065 \mathrm{X}_{1}+0,082 \mathrm{X}_{2}+0,112 \mathrm{X}_{3}+0,123 \mathrm{X}_{4}+0,067 \mathrm{X}_{5}$ $+0,045$ 
Kata Kunci : Preferensi

Konsumen, Kefir

\section{Pendahuluan}

Kefir adalah susu terfermentasi yang berasal dari Kaukasus dan telah diproduksi ratusan tahun yang lalu Fermentasi pada kefir sebagai akibat kerja bakteri dan ragi yang terdapat pada grain kefir. Selama proses pembuatan kefir akan terjadi perubahan komposisi zat gizi dan unsur-unsur yang lain. Komposisi kimia kefir menurut Codex Standard For Fermented Milks Codex Stan 243-2003 yang dikeluarkan oleh FAO/WHO (2001) adalah : protein minimal 2,8\% (w/w), lemak susu < $10 \%$ $(\mathrm{m} / \mathrm{m})$, keasaman tertitrasi yang dinyatakan sebagai \% asam laktat minimal 0,6 \% (m/m), jumlah mikroorganisme spesifik yang merupakan kultur stater minimal $10^{7}$ (cfu/g) dan ragi minimal $10^{4}$ (cfu/g).

Selama proses fermentasi akan terjadi hidrolisis protein dalam susu menjadi peptida dan asamasam amino. Pembentukan asam amino selama proses fermentasi adalah valin, leusin, lisin, dan serin sedangkan kadar alanin dan asam aspartat mengalami peningkatan dibandingkan dengan yang terdapat dalam susu segar (Bottazzi et al., 1994).

Kefir merupakan bahan pangan fungsional yang bermanfaat bagi kesehatan manusia. Menurut Farnworth (2005), bahan pangan fungsional adalah salah satu bahan pangan yang dikonsumsi sebagai bagian dari makananan, dan diharapkan mempunyai manfaat secara psikologi dan atau mengurangi resiko penyakit kronik diluar dasar fungsi-fungsi nutrisional. Konsumen berharap dengan mengkonsumsi kefir ada manfaat tertentu bagi tubuh.

Sebagai salah satu bahan pangan fungsional dan merupakan bagian dari bahan pangan probiotik, kefir mengandung komponen-komponen bioaktif yang bermanfaat bagi kesehatan manusia. Bioaktif yang ada dalam kefir adalah mikroorganime (hidup atau mati), metabolit-metabolit yang terbentuk selama fermentasi (antibiotik atau bakterisida), atau produk-produk sebagai akibat pemecahan dari matriks bahan pangan seperti peptida.

Konsumen dalam menjatuhkan pilihan terhadap produk-produk bahan pangan tidak terlepas dari pandangan tentang atribut yang ada pada bahan pangan, dan atribut tersebut akan berpengaruh terhadap preferensi suatu produk. Preferensi konsumen terhadap kefir merupakan bagian penting dari perilaku konsumen, dan dapat dijadikan sebagai salah satu pijakan produsen dan pemasar untuk merancang produk secara tepat, karena kefir menurut Otes and Cagindi (2003) merupakan produk yang mempunyai karakteristik organoleptik yang unik yaitu fizzy, terasa asam dan menyegarkan. Menurut Granato et al. (2010), peningkatan respon konsumen terhadap bahan pangan fungsional berkaitan dengan kesehatan, dan pihak industri telah merespon dengan mengembangkan produkproduk bahan pangan fungsional untuk memenuhi permintaan pasar.

Preferensi merupakan output dari kegiatan yang mempertimbangkan atau mengevaluasi beberapa atribut produk yang mengarah kepada jenis produk, karakteristik, organoleptik produk, dan manfaat produk terhadap kesehatan konsumen. Preferensi itu sendiri secara umum dipengaruhi motivasi konsumen yang berasal dari internal dan eksternal.

\section{Tujuan penelitian}

Tujuan penelitian ini adalah sebagai berikut :

1. Menganalisis faktor-faktor yang berpengaruh terhadap keputusan pembelian kefir susu kambing.

2. Menganalisis faktor-faktor yang berpengaruh terhadap preferensi konsumen kefir susu kambing

\section{METODE PENELITIAN \\ Tempat Penelitian}

Lokasi penelitian adalah konsumen kefir susu kambing yang ada di wilayah Kabupaten dan Kota Malang di Kecamatan Kedungkandang, Kecamatan Lowokwaru dan Kecamatan Blimbing. 


\section{Sampel Penelitian}

Populasi dalam penelitian ini adalah seluruh konsumen kefir susu kambing di 3 Kecamatan sebanyak 95 responden, sedangkan populasi targetnya adalah konsumen kefir susu kambing di Jawa Timur.

\section{Metode Penelitian}

Metode penelitian yang digunakan adalah survey (Nasir, 2005). Pengambilan sampel dilakukan melalui 3 tahap yaitu :

1. Penentuan sampel lokasi dilakukan dengan metode Purposive Sampling (Nasir, 2005).

2. Pengambilan sampel responden yang mengkonsumsi kefir susu kambing dilakukan secara aksidental ( Nasir, 2005).

3. Jumlah konsumen kefir yang diambil antara 100-200 orang (Ghozali, 2004).

\section{Metode Pengambilan Data}

Data penelitian terdiri dari data primer dan data sekunder. Data primer diperoleh dengan wawancara langsung dengan konsumen kefir susu kambing, dan data sekunder berasal dari data statistik kependudukan tempat penelitian. Instrumen penelitian ini adalah berupa kuisioner dengan skala Likert (Nasir, 2005) dengan menggunakan 5 item skor tingkatan.

\section{Faktor-Faktor Yang Berpengaruh Terhadap Keputusan Pembelian}

Faktor-faktor dan indikator-indikator perilaku konsumen dalam pembelian kefir susu kambing adalah :

1. Jaminan Keamanan $\left(X_{1}\right)$

1. Halal $\left(\mathrm{X}_{11}\right)$

2. Self life $\left(\mathrm{X}_{12}\right)$

3. Ingredient $\left(\mathrm{X}_{13}\right)$

4. Kemasan $\left(\mathrm{X}_{14}\right)$

5. Brand name $\left(\mathrm{X}_{15}\right)$

6. Freshness $\left(\mathrm{X}_{16}\right)$

7. Hygieness $\left(\mathrm{X}_{17}\right)$

2. Kepuasan Fisiologis $\left(X_{2}\right)$

1. Nilai gizi $\left(X_{21}\right)$

2. Flavour $\left(\mathrm{X}_{22}\right)$

3. Kesehatan $\left(\mathrm{X}_{23}\right)$

3. Kepuasan Sosiologis $\left(X_{3}\right)$

1. Sosialisasi $\left(\mathrm{X}_{31}\right)$

3. Gengsi $\left(\mathrm{X}_{32}\right)$

4. Tren $\left(\mathrm{X}_{33}\right)$

5. lifestyle $\left(\mathrm{X}_{34}\right)$

6. Kebiasaan $\left(\mathrm{X}_{35}\right)$

4. Kepuasan Harga Diri $\left(X_{4}\right)$

1. Produk eksklusif $\left(\mathrm{X}_{41}\right)$

2. Nature Product $\left(\mathrm{X}_{42}\right)$

3. Konsumen tertentu $\left(\mathrm{X}_{43}\right)$

4. Produk organik $\left(X_{44}\right)$

5. Produk terbatas $\left(X_{45}\right)$

5. Kepuasan Aktualisasi $\left(X_{5}\right)$

1. Pergaulan $\left(\mathrm{X}_{51}\right)$

2. Terpandang $\left(\mathrm{X}_{52}\right)$

3. Pendidikan $\left(\mathrm{X}_{53}\right)$

Pertimbangan Pembelian $\left(\mathbf{X}_{6}\right)$

1. Kualitas fisiko-kimia (nilai gizi) $\left(\mathrm{X}_{61}\right)$

2. Harga $\left(\mathrm{X}_{62}\right)$ 


\section{Promosi $\left(\mathrm{X}_{63}\right)$ \\ 4. Tempat penjualan $\left(\mathrm{X}_{64}\right)$}

Faktor-Faktor Yang Berpengaruh Terhadap Preferensi Konsumen

Faktor-faktor yang berpengaruh terhadap prefenrensi konsumen adalah :

1. Kehalalan $\left(\mathrm{X}_{1}\right)$

2. Ingredient $\left(\mathrm{X}_{2}\right)$

3. Nilai gizi $\left(\mathrm{X}_{3}\right)$

4. Kesehatan $\left(\mathrm{X}_{4}\right)$

5. Kebiasaan $\left(\mathrm{X}_{5}\right)$

6. Nature product $\left(\mathrm{X}_{6}\right)$

Indikator yang yang berpengaruh terhadap preferensi konsumen adalah :

1. Organoleptik $\left(\mathrm{X}_{1}\right)$

2. Fisiko-kimia $\left(\mathrm{X}_{2}\right)$

3. Tempat penjualan $\left(\mathrm{X}_{3}\right)$

4. Kepraktisan $\left(\mathrm{X}_{4}\right)$

5. Manfaat produk $\left(\mathrm{X}_{5}\right)$

\section{Analisis Data}

Analisis faktor dalam penelitian ini adalah analisis faktor eksploratori. Suatu penelitian bersifat ekploratif yang bertujuan untuk mengetahui faktor-faktor penyusunnya.

Sumbangan variabel yang mempengaruhi keputusan pembelian kefir dan preferensi konsumen diuji dengan menggunakan regresi linier berganda. Hubungan sebab akibat dari variabel secara matematis adalah:

$Y=a+\beta_{1} X_{1}+\beta_{2} X_{2}+\beta_{3} X_{3}+\beta_{4} X_{4}+\ldots \ldots+\beta_{n} X_{n}+e$

Reliabilitas dan validitas alat ukur dilakukan dengan uji Statistic Packet for Social Science (SPSS).

\section{HASIL PENELITIAN DAN PEMBAHASAN}

\section{Faktor-faktor yang Berpengaruh Terhadap Keputusan Pembelian}

Pendidikan konsumen yang paling banyak adalah SMA sebesar 38,36\%. Partisipan responden wanita yang mengkonsumsi kefir lebih banyak dibandingkan dengan pria. Wanita kebanyakan mengatur peranan dalam keuangan rumah tangga dibandingkan dengan pria. Menurut Aktas and Cebirbay (2010), faktor demografi seperti gender, umur, pekerjaan, dan pendidikan sangat berpengaruh terhadap akseptabilitas bahan pangan fungsional. Begitu juga dengan manfaat bahan pangan tersebut terhadap kesehatan (Hasler, 2002). Keputusan pembelian oleh konsumen terhadap kéfir susu kambing menggunakan pendekatan análisis faktor. Menurut Sharma (1996), análisis faktor dapat digunakan manakala variabel yang digunakan memiliki tingkat keterkaitan yang tinggi, dan indikasi tingkat keterkaitan tersebut dapat ditentukan dengan Uji Keiser Meyer Olkin (KMO) dan Mesuares Sampling of Adequacy (MSA)

Hasil pengujian terhadap 5 variabel yang diteliti yaitu jaminan keamanan, kepuasan fisiologis, kepuasan sosial, kepuasan harga diri, dan aktualisasi (variabel X) mempunyai nilai Cronbach alpha 0,719 dan untuk variabel Y mempunyai nilai Cronbach alpha 6,15 yang berarti instrument yang digunakan mempunyai keandalan, karena nilai alfa lebih besar 0,6. Menurut Sakaran (2003), suatu instrument dikatakan reliable jika mempunyai nilai Cronbach alpha lebih besar 0,6.

Hasil pengujian validitas terhadap 5 variabel didapatkan nilai Kaiser Meyer Olkin (KMO) sebesar 0,793. Nilai KMO tersebut lebih dari 0,5 yang berarti bahwa jumlah sampel sudah memenuhi kecukupan dalam uji factor. Uji Bartlett's Test of Sphericity didapatkan nilai sebesar 154,830 dengan signifikansi 0,00 , serta faktor loading terkecil 0,619 dan terbesar 0,722 yang menunjukkan bahwa secara keseluruhan terjadi korelasi secara signifikan antar variabel pada taraf 0,00. Hair et al. (2006) dan Wijaya (2010) melaporkan bahwa instrumen analisis faktor dikatakan valid apabila mempunyai 
nilai Kaiser Meyer Olkin lebih dari 0,50 dengan nilai loading lebih besar 0,4 karena sampel yang diambil telah memenuhi persyaratan kecukupan.

Uji regresi berganda terhadap faktor-faktor yang mempengaruhi perilaku konsumen yang diwujudkan dengan pembelian kefir susu kambing seperti pada Tabel 1. Faktor kepuasan fisiologis mempunyai nilai koefisien regresi dan t hitung terbesar masing-masing 0,159 dengan 3,739, sedangkan aktualisasi mempunyai nilai koefisien regresi dan t hitung terkecil masing-masing 0,048 dan 1,615 .

Tabel 1. Hasil Regresi Berganda Faktor-faktor yang Berpengaruh terhadap Pertimbangan Pembelian

\begin{tabular}{|l|r|r|r|r|r|}
\hline \multirow{2}{*}{ Model } & \multicolumn{2}{|c|}{$\begin{array}{c}\text { Unstandardized } \\
\text { Coefficients }\end{array}$} & \multicolumn{1}{c|}{$\begin{array}{c}\text { Standardized } \\
\text { Coefficients }\end{array}$} & \multirow{2}{*}{$\mathrm{t}$} & \multirow{2}{*}{ Sig. } \\
\cline { 2 - 4 } & \multicolumn{1}{|c|}{$\mathrm{B}$} & Std. Error & \multicolumn{1}{c|}{ Beta } & & \\
\hline (Constant) & 0,629 & 0,461 & & 1,365 & 0,175 \\
\hline Jaminan keamanan & 0,056 & 0,023 & 0,207 & 2,391 & 0,019 \\
\hline $\begin{array}{l}\text { Kepuasan } \\
\text { fisiologis }\end{array}$ & 0,159 & 0,043 & 0,349 & 3,739 & 0,000 \\
\hline $\begin{array}{l}\text { Kepuasan } \\
\text { sosiologis }\end{array}$ & 0,080 & 0,024 & 0,309 & 3,332 & 0,001 \\
\hline $\begin{array}{l}\text { Kepuasan harga } \\
\text { diri }\end{array}$ & $-0,053$ & 0,027 & $-0,202$ & $-1,977$ & 0,051 \\
\hline Aktualisasi & 0,048 & 0,029 & 0,155 & 1,615 & 0,109 \\
\hline
\end{tabular}

Analisis varian dengan prediktor antara variabel independent (kepuasan fisiologis, kepuasan sosiologis, jaminan keamanan, kepuasan harga diri, dan aktualisasi) dengan variabel dependent didapatkan $\mathrm{F}$ hitung > F tabel yang berarti secara bersama-sama kelima faktor berpengaruh secara signifikan terhadap keputusan pembelian kefir susu kambing. Hasil persamaan regresi pada penelitian ini adalah $\mathrm{Y}=0,629+0,056 \mathrm{X}_{1}+0,159 \mathrm{X}_{2}+0,080 \mathrm{X}_{3}-0,053+0,048 \mathrm{X}_{5}$.

Tabel 1 menunjukkan bahwa faktor jaminan keamanan, kepuasan fisiologis, kepuasan sosiologis, dan aktualisasi mempunyai hubungan positif dengan keputusan pembelian konsumen, sedangkan kepuasan harga diri mempunyai hubungan negatif. Hubungan positif menunjukkan bahwa faktor jaminan keamanan, kepuasan fisiologis, kepuasan sosiologis, dan aktualisasi searah dengan keputusan pembelian kefir susu kambing, dan menunjukkan trend yang terus meningkat dalam mengkonsumsi kefir susu kambang, sedangkan kepuasan harga diri menunjukkan sebaliknya.

Konsumen selalu konsisten terhadap bahan pangan yang dibelinya, terutama terhadap resiko keamanan pangan, indikasinya adalah keputusan pembelian dimotivasi untuk melindungi kesehatan (Baker, 2003). Konsumen dalam memutuskan pembelian terhadap produk melalui tahapan pertimbangan-pertimbangan tertentu sesuai dengan kebutuhan. Menurut Mangkunegara (2006), teori Maslow meliputi semua kebutuhan yang diperlukan manusia.. Dikatakan pula bahwa kebutuhan manusia secara hirarki meliputi kebutuhan fisiologis, rasa aman, sosial, aktualisasi, dan kebutuhan harga diri.

Hasil penelitian menunjukkan bahwa secara hirarki faktor kepuasan fisiologis menempati urutan pertama dengan nilai beta 0,159 , kepuasan sosiologis urutan kedua dengan nilai beta 0,080, jaminan keamanan urutan ketiga dengan nilai beta 0,058, kepuasan harga diri urutan keempat dengan nilai beta 0,53 , dan aktualisasi urutan kelima dengan nilai beta 0,048 . Nilai beta menunjukkan besarnya kekuatan pengaruh terhadap keputusan pembelian oleh konsumen. Hal ini menyerupai dengan teori kebutuhan Maslow bahwa konsumen dewasa mampu memuaskan kebutuhan fisiologisnya kira-kira 85\%, jaminan rasa aman 70\%, kepuasan sosiologis 50\%, kepuasan harga diri 40\%, dan aktualisasi 10\% (Mangkunegaran, 2005).

Kelima variabel yang merupakan faktor yang berpengaruh terhadap keptusan pembelian seyogyanya terpenuhi sebagai atribut produk secara umum. Kepuasan fisiologis merupakan faktor pertama yang berpengaruh yang akan menjadi jaminan bahwa kefir susu kambing benar-benar produk 
yang bermanfaat secara fisiologis sebagai bahan pangan fungsional. Sebagian masyarakat mempercayai kefir sebagai minuman yang bermanfaat bagi kesehatan, dan kefir merupakan salah satu bahan pangan fungsional, sehingga produk tersebut oleh konsumen sudah dianggap sebagai kebutuhan fisiologis karena berkaitan dengan kesehatan. Engel (2006) menyatakan bahwa kebutuhan fisiologis merupakan kebutuhan yang harus terpenuhi sebelum kebutuhan-kebutuhan yang lain terpenuhi, terutama yang menyangkut kelangsungan hidup seseorang termasuk kesehatan, dan kebutuhan ini sangat dominan dibandingkan dengan kebutuhan-kebutuhan yang lain.

Pengertian bahan pangan fungsional menurut Anonymous (2004) dalam Farnworth (2005) adalah salah satu bahan pangan yang dikonsumsi sebagai bagian dari makananan, dan diharapkan mempunyai manfaat secara psikologi dan atau mengurangi resiko penyakit kronik diluar dasar fungsifungsi nutrisional. Konsumen berharap dengan mengkonsumsi kefir ada manfaat tertentu bagi kesehatan tubuh.

Manfaat suatu produk atau fungsi utilitas produk atau jaminan fungsional produk merupakan faktor yang penting pada keputusan pembelian kefir susu kambing. Horsono, et al. (1990) melaporkan bahwa kefir telah diklaim sebagai bahan pangan fungsional yang mampu menyembuhkan penyakit. Fungsi utilitas yang dimiliki kefir maka, perilaku konsumen bisa diarahkan ke pertimbangan pembelian kefir.

Memahami perilaku konsumen didasarkan pada pemikiran bahwa konsumen merupakan pasar produk. Jika produk menurut konsumen mampu memenuhi kebutuhan dan keinginannya, konsumen akan memutuskan membeli yang diinginkan. Produsen dalam rangka memenuhi keinginan konsumen, perlu strategi pemasaran yang dikaitkan dengan keunggulan atas produk. Frewer et al. (2003) melaporkan bahwa produsen bahan pangan saat ini telah menggunakan kriteria kesehatan pada produk bahan pangan fungsional yang diproduksinya dengan harapan memiliki nilai tambah yang positif bagi kesehatan.

Menurut Asseal (1998), tiga faktor yang mempengaruhi pengambilan keputusan untuk memilih suatu produk oleh konsumen yaitu faktor individu yang meliputi pendidikan dan pengahasilan, faktor lingkungan, dan faktor strategi pemasaran. Anonimous (2004) menambahkan bahwa permintaan konsumen terhadap produk yang aman dikonsumsi merupakan faktor yang harus dipenuhi karena memberikan rasa aman pada konsumen.

Pengaruh perilaku konsumen yang besar terhdap keputusan pembelian adalah demografi, sosial, ekonomi, budaya, psikologis dan faktor pribadi lainnya, sebagian besar faktor-faktor di luar kendali dan pengaruh pemasar. (Czinkota et al., 2000;. Czinkota and Kotabe; 2001; Dibb et al., 2001; Boyd et al., 2002.; Salomon and Stuart, 2003). Namun demikian alat pemasaran yang paling menonjol selama ini menggunakan kaidah $4 \mathrm{P}$ yaitu product, price, place, dan promotion ( produk, harga, tempat dan promosi ), yang dikenal sebagai bauran pemasaran, dan sebagai alat yang dapat mempengaruhi perilaku konsumen adalah termasuk interaksi konsumen-penjual (Kotler and Armstrong, 2001; Kotler, 2003; Brassington and Pettitt, 2003). Khusus terhadap bahan pangan, Traill (1999) menyatakan bahwa proses terjadinya keputusan pembelian terhadap bahan pangan sangat dipengaruhi kepuasan fisiologis dan persepsi organoleptis.

Produk kefir oleh sebagian masyarakat masih merupakan bahan pangan fungsional yang relatif asing, sehingga bauran pemasaran sebagai indikator keputusan pembelian seperti produk, harga, tempat, promosi, sangat berpengaruh. Namun menurut Ettenson et al. (1988), penerimaan konsumen yang tinggi terhadap produk asing (baru) dipengaruhi oleh income yang tinggi dan pendidikan. Ditambahkan oleh Grazyna (2005) bahwa konsumen membeli suatu produk tergantung pada budget yang dimiliki, dan budget tersebut diperoleh dari keluarganya. Hasil penelitian Watanabe et al. (1998) menunjukkan bahwa pengaruh demografi, sosio-ekonomi dan gaya hidup berpengaruh terhadap keputusan pembelian. Hasil penelitian tersebut menunjukkan bahwa konsumen yang peduli terhadap kesehatan cenderung memilih produk susu tawar (plain) dan susu fermentasi dibandingkan dengan minuman ringan (soft drink), sedangkan pria cenderung memilih minuman ringan dan susu yang beraroma. 
Income pada konsumen akan berpengaruh terhadap perubahan sosial ekonomi, dan akan berdampak pada keputusan pembelian oleh konsumen, baik untuk kebutuhan primer maupun skunder. Hasil penelitian Tedjakusuma dkk. (2001) tentang keputusan pembelian air minum mineral menunjukkan bahwa keputusan pembelitian dipengaruhi oleh faktor pendidikan, penghasilan konsumen, pengaruh lingkungan, sosial, dan strategi pemasaran. Dikatakan pula bahwa pendidikan berkaitan dengan daya beli, karena pendidikan berkorelasi positip terhadap pendapatan.

Harga kefir susu kambing termasuk bahan pangan fungsional yang berharga cukup mahal yaitu Rp 100.000,- Rp 120.000,-/liter, sehingga konsumen tidak mudah menjatuhkan keputusan pembelian. Menurut Kottler (1997), untuk barang-barang yang berharga mahal memerlukan keterlibatan yang tinggi dari konsumen. Hal ini disebabkan konsumen perlu mengumpulkan dan mengevaluasi sejumlah informasi yang berkaitan dengan produk yang dibelinya. Informasi yang berkaitan dengan keputusan pembelian kefir susu kambing adalah informasi yang sesuai dengan kebutuhan, yaitu faktor jaminan keamanan, kepuasan fisiologis, kepuasan sosiologis, kepuasan harga diri, dan kepuasan aktualisasi. Kelima keputuhan tersebut yang paling dominan adalah kepuasan fisiologis yang mempunyai indikator kesehatan.

\section{Faktor-Faktor Yang Berpengaruh Terhadap Preferensi Konsumen}

Hasil pengujian reliabilitas terhadap 6 faktor yaitu halal, ingredient, nilai gizi, kesehatan, kebiasaan, dan nature product yang merupakan variabel X mempunyai nilai Cronbach alpha 0,604 dan untuk variabel Y mempunyai nilai Cronbach alpha 0,660 yang berarti instrument yang digunakan mempunyai keandalan dan sesuai dengan persyaratan. Sakaran (2003) melaporkan bahwa suatu instrument dikatakan reliable jika nilai Cronbach alpha lebih besar 0,6.

Hasil pengujian validitas terhadap 6 faktor menunjukkan bahwa nilai Kaiser Meyer Olkin (KMO) sebesar 0,678, Bartlett's Test of Sphericity sebesar 71,705 dengan signifikansi 0,00, dan faktor loading lebih besar 0,4. Analisis tersebut menunjukkan bahwa faktor halal, ingredient, nilai gizi, kesehatan, kebiasaan, dan nature product tergolong valid dengan nilai Kaiser Meyer Olkin (KMO) lebih besar 0,6 dengan faktor loading lebih besar dari 0,4. Menurut Wijaya (2009), persyaratan suatu instrumen dikatakan valid apabila mempunyai faktor loading lebih besar dari 0,4 ,

Uji regresi berganda terhadap faktor-faktor yang mempengaruhi perilaku konsumen yang diwujudkan dengan pembelian kefir susu kambing seperti pada Tabel 2.

Tabel 2. Hasil Regresi Berganda Faktor-faktor yang Berpengaruh terhadap Preferensi Konsumen

\begin{tabular}{|l|c|c|c|c|c|}
\hline \multirow{2}{*}{ Model } & \multicolumn{2}{|c|}{$\begin{array}{c}\text { Unstandardized } \\
\text { Coefficients }\end{array}$} & $\begin{array}{c}\text { Standize } \\
\text { Coefficients }\end{array}$ & \multirow{2}{*}{$\mathrm{t}$} & \multirow{2}{*}{ Sig. } \\
\cline { 2 - 4 } & $\mathrm{B}$ & Std. Error & Beta & & \\
\hline (Constant) & 1,857 & 0,243 & & 7,646 & 0,000 \\
\hline Halal & 0,065 & 0,029 & 0,170 & 2,291 & 0,024 \\
\hline Ingredient & 0,082 & 0,035 & 0,174 & 2,358 & 0,020 \\
\hline Nilai Gizi & 0,112 & 0,034 & 0,255 & 3,282 & 0,001 \\
\hline Kesehatan & 0,123 & 0,031 & 0,299 & 3,926 & 0,000 \\
\hline Kebiasaan & 0,067 & 0,025 & 0,215 & 2,680 & 0,009 \\
\hline Nature Product & 0,045 & 0,038 & 0,086 & 1,181 & 0,240 \\
\hline
\end{tabular}

Dependent variabel: Pertimbangan pembelian

Analisis varian dengan prediktor antara variabel independent (halal, ingredient, nilai gizi, kesehatan, kebiasaan, dan nature product) dengan variabel dependent didapatkan $\mathrm{F}$ hitung $>\mathrm{F}$ tabel yang berarti secara bersama-sama keenam faktor tersebut berpengaruh secara signifikan terhadap preferensi konsumen kefir susu kambing. Persamaan regresi pada penelitian ini adalah $\mathrm{Y}=1,857+0,065 \mathrm{X}_{1}+0,082 \mathrm{X}_{2}+0,112 \mathrm{X}_{3}+0,067+0,045 \mathrm{X}_{5}$. Koefisien regresi variabel halal, ingredient, nilai gizi, kesehatan, kebiasaan, dan nature product menunjukkan angka positif atau searah dengan dengan preferensi konsumen (Y). Semakin konsumen percaya bahwa produk yang dibelinya 
mempunyai efek terhadap kesehatan maka preferensi terhadap kefir susu kambing akan semakin meningkat, begitu juga terhadap variabel-variabel yang lain. Namun, besaran nilai koefisien regresi dan $\mathrm{t}$ hitung diantara variabel terjadi perbedaan.

Faktor kesehatan mempunyai nilai koefisien regresi dan $\mathrm{t}$ hitung terbesar dibandingkan dengan faktor lain yaitu masing-masing 0,132 dan 3,926, sedangkan nature product mempunyai nilai koefisien regresi dan thitung terkecil masing-masing 0,045 dan 1,181. Semakin tinggi nilai koefisien regresi dan t hitung, semakin besar pengaruhnya terhadap preferensi konsumen. Hasil tersebut sejalan dengan penelitian yang dilakukan oleh Humayun and Hasnu (2009) terhadap konsumen produkproduk susu menunjukkan bahwa faktor kesehatan dianggap sebagai kebutuhan fungsional dan merupakan faktor utama yang berpengaruh terhadap preferensi konsumen, sedangkan faktor citarasa produk dan faktor lingkungan merupakan faktor kedua dan ketiga yang berpengaruh terhadap preferensi konsumen. Dikatakan pula bahwa tidak ada hubungan antara faktor kesehatan dengan citarasa produk.

Kefir sebagai bahan pangan fungsional dipercaya mampu menyembuhkan penyakit (Farnworth, 2005). Kepercayaan terhadap bahan pangan yang bermanfaat terhadap kesehatan merupakan motivator penting terhadap perilaku konsumen (Stanton et al., 2001). Semua faktor yang berpengaruh terhadap preferensi konsumen mempunyai image positif yang ditunjukkan dengan koefisien regresi positif. Image positif pada suatu produk akan memberikan pengaruh terhadap preferensi konsumen. Menurut (Siro et al., 2008), keberhasilan pengembangan produk-produk susu probiotik sangat dipengaruhi oleh kesan yang baik terhadap konsumen.

Penerimaan konsep bahan pangan fungsional seperti kefir susu kambing oleh konsumen merupakan faktor yang berpengaruh terhadap preferensi konsumen. Faktor kesehatan, nilai gizi, nature product, dan ingredient merupakan faktor kebutuhan fisiologis (physiological needs) yang berkaitan dengan kepentingan kelangsungan hidup secara biologis (biological life) (Assadi,, 2003), dan juga kehalalan produk. Penerimaan oleh konsumen terutama ditentukan oleh kepedulian terhadap kesehatan, keakraban dengan bahan pangan fungsional, functional ingredients, dan natural product (Siro et al., 2008).

Proses terjadinya preferensi konsumen terhadap kefir sama dengan bahan pangan yang bersifat consumer goods (bahan pangan untuk konsumsi sehari-hari), yaitu melalui tahapan cobacoba yang dipengaruhi oleh promosi, pergaulan dan lain-lain. Setelah melalui pembelian dan mengalami kepuasan, pembelian produk tersebut akan dilakukan secara berulang.

\subsection{Kesimpulan}

\section{KESIMPULAN DAN SARAN}

Faktor-faktor yang berpengaruh terhadap pengambilan keputusan pembelian kefir susu kambing adalah faktor jaminan keamanan, kepuasan fisiologis, kepuasan sosiologis, kepuasan harga diri, dan aktualisasi dengan persamaan regresi berganda $\mathrm{Y}=0,629+0,056 \mathrm{X}_{1}+0,159 \mathrm{X}_{2}+0,080 \mathrm{X}_{3}$ $0,053 \mathrm{X}_{4}+0,048 \mathrm{X}_{5}$.

Faktor-faktor yang berpengaruh terhadap preferensi konsumen adalah faktor halal, ingredient, nilai gizi, kesehatan, kebiasaan, dan faktor nature produc dengan persamaan regresi berganda $\mathrm{Y}=1,857+0,065 \mathrm{X}_{1}+0,082 \mathrm{X}_{2}+0,112 \mathrm{X}_{3}+0,123 \mathrm{X}_{4}+0,067 \mathrm{X}_{5}+0,045 \mathrm{X}_{6}$.

\subsection{Saran-saran}

Perlu desain rekayasa untuk produk kefir yang disesuaikan dengan kebutuhan konsumen, dan adanya penelitian lebih lanjut tentang bagaimana memproteksi bioaktif yang ada dalam kefir, terutama $\beta$-laktoglobulin yang dikaitkan dengan peta kesehatan konsumen, dan adanya edukasi terhadap konsumen tentang menfaat kefir susu kambing. 


\section{DAFTAR PUSTAKA}

Aaker D.A, Kumar, V. and Day, G.S., 1995. Marketing Research. John, Wiley and Sons, Inc. New York.

Adamczyk, G. 2005. Food Preference of Young Consumers on The Example of Milk. Roezniki Akademii Rolniezej W Posnantu.Ccclxvii.

Asseal, H., 1998. Consumer Behaviour and Marketing Action. Vol I. Kent Publishin Company. Boston.

Engel , J.F., Blackwell, R.D. and Miniard, P.W., 2006. Consumer Behaviour. $8^{\text {th }}$ Ed. The Dryden Press. Philadelphia.

Krasaekoopt, W. and Kitsawad, K., 2010. Sensory Characteristics and Consumer Acceptance of Fruit Juice Containing Probioitcs Beads in Thailand. Au J.T., 14(1): 33-38.

Libudzisz, Z. and Piatkiewicz, A., 1990. Kefir Production in Poland. Dairy Ind. Int., 55:31-32.

Liljander, V and Strandvik,T., 1996. Emotions in Service Satisfaction. Int. J. Service Industry Manag., 8(2): 148169.

Liu, J.R. and Lin, C.W., 2000. Production of Kefir From Soymilk With Or Without Added Glucose, Lactose, or Sucrose. J. Food Sci., 65(4): 716-719.

Loudon, D.L. and Bitta, A.J.D., 1988. Consumer Behaviour : Concept and Aplications, $2^{\text {nd }}$ Edition. McgrawHill Book Company, Singapore.

Lucas, A., Sodini, I., Monnet, P., Jolivet, P. and Corrieu, G., 2004. Probiotic Counts and Acidifacation in Fermented Milks Supplemented with Milk Protein Hydrolysates. Int. Dairy J., 14(1):4753.

Maholtra, N.K., 1993. Marketing Research: An Applied Orientation. Printice Hall. Upper Saddle Rive, New Jersey.

Mangkunegara, A.P., 2005. Perilaku Konsumen. Ed. Revisi. PT. Revika, Bandung.

Murofushi, M., Mizuguchi, J., Aibara, K. and Matuhasi, T., 1986. Immunopotentiative Effect of Polysaccharide From Kefir Grain, Kgfc, Administered Orally in Mice.

Immunopharmacology, 12:29-35.

Mutlu, S., 2007. Consumer Attitute and Behaviour Towards Organic Food: Cross-culture study of Turky and Germany. Institute for Agricultural Policy and Markets. Stuttgart-Hohenheim. Germany.

Nasir, M., 2005. Metod Penelitian. Cet. 6. Ghalia Indonesia. Bogor.

Paucean, A., Rotar, MA, Jimborean, M., Mudura, E. and Socaciu, C. 2009. A Study on Sensory Characteristics of A Kefir Type Produced Using Starter Cultures and Brewer's Yeast. J. Agroalim. Proc. and Tech., 15(2), 267-272. 
Pellisier, J.P. and Manchon, P., 1976. Comperative Study of The Bitter Taste of Enzymic Hydrolysates From Cow, Ewe, and Goat Caseins. J. Food Sci., 41: 2-31.

Prabakaran, S. and Damodaran, S., 1997. Thermal Unfolding of BLactoglobulin: Characterization of initial Unfolding Events Responsible for Heatinduced Aggregation. J. Agric. and Food Chem., 45: 4303-4308.

Radiosunu, 1987. Managemen Pemasaran. Suatu Pendekatan Analisis. BPFE. Yogyakarta.

Rangkuti, F., 2001. Riset Pemasaran. Pt. Gramedia Pustaka Utama. Jakarta.

Rao, A.R and Monroe, K. B., 1989. The Effect of Price, Brand Name, and Store Name Buyers Perceptions of Products Quality: An integration Review. J. Marketing Res., 26:351-357.

Saleh, E., 2004. Dasar Pengolahan Susu Dan Hasil Ikutan Ternak. Digitized By Usu Digital Library. Medan, 1-24.

Schmelz, E.M., and Merill, A.H., 1998. Ceramides and Ceramide Metabolites in Cell Regulation: Evident for Dietarysphingolipids As inhibitors of Colon Carcinogenesis. Nutrition, 14:717719.

Schlegel, Hg. 1994. Mikrobiologi Umum. Edisi Keenam. Gadjah Mada University Press, Yogyakarta.

Schoevers, A. and Britz, T.J. 2003. Influence of Different Culturing Conditions on Kefir Grain Increase. In. J. Dairy Tech., 56(3): 183-187.

Shavit, E., 2008. Renewed Interest in Kefir, the Ancient Elixir of Longevity. Volume 1:2 Summer Bul., 1(2): 14-18.

Sharma, S., 1996. Applied Multivariate Techniques. John Wiley and Sons, Inc., New York.

Shihata, A. and Shah, N.P., 2000. Proteolytic Profiles of Yogurt and Probiotic Bacteria. Int. Dairy J., 10: 401-408.

Song, C. Y., Chen, W. L., Yang, M. C., Huang, J. P. and Mao. S. J. T. 2005. Epitope mapping of a monoclonal antibody specific to bovinedry milk: Involvement of residues $66-76$ of strand D in thermal denatured $\beta$-lactoglobulin. J. Biol. Chem. 280:3574-358

Tedjakusuma, R. dan Muryani, S.H., 2001. Analisis Faktor Yang Mempengaruhi Perilaku Konsumen Dalam Pembelian Air Minum Mineral Di Kota Surabaya. J. Pen. Dinamika Sosial, 2: 50-58.

Ulusoy, B.H., Çolak. H, Hampikyan.H, and Erkan, M.E., 2007. An in Vitro Study on The Antibacterial Effect of Kefir Against Some FoodBorne Pathogens. Turk Mikrobiyol Cem Derg., 37 (2): 103-107.

Umar, H., 2005. Riset Pemasaran Dan Perilaku Konsumen. Gramedia Pustaka Utama. Jakarta Research Center. Jakarta. 
Usmiati, S. dan Sudono, A. 2004. Pengaruh Starter Kombinasi Bakteri Dan Khamir. Terhadap Sifat Fisiko-kimia dan Sensori Kefir. J. Pascapanen, I(1): 12-21.

Valkonen, K. H.,. Marttinen, N., Malinen, H.L., Jaakola, V.P. and. Alatossava, T., 2011. Purification and Characterization of $\beta$-Lactoglobulin Genetic Variant A and B By Using Preparative Elution Electrophoresis and Isoelectric Focusing. Preparative Electrophoresis. Bulletin Bio Rad,. Tech. Note no. 2262, Hercules.

Van den Berg, J.T.C., 1987. Higiene Susu dan Teknologi Produk Susu. Diterjemahkan oleh Purnomo, H., Padaga, M.C. dan Sawitri, M.E. Program Studi Teknologi Hasil Ternak. Fakultas Peternakan. Universitas Brawijaya, Malang.

Walter, E.H.M. 2007. Testing The Sensory Acceptability of Biltong formulated With Different Spces. J. Agric. Res., 2: 574-577.

Wang, Y., Zheng, Y, Jiang, M., Liang, C. and Liu, Z.L., 2011. Comparison of The Biochemical Components and Characteristic of Milk Between Tibetan Sheep Goat in Neighboring Area. Afr. J. Biotech.10(11): 2092-2100.

Xiao, J.Z., Kondo, S., Takahashi, N., Miyaji, K., Oshika, K., Hiramatsu, A. Iwatsuki, K., Kokubo, S. and Hosono, A., 2003. Effect of Milk Products Fermented by Bifidobacterium Longum on Blood Lipids in Rats and Healthy Adult Male Volunteers. J. Dairy Sci., 86:2452-2461.

Xu, Z. M., Emmanouelidou, D. G., Raphaelides, S. N. and Antoniou, K. D., 2008. Effects of Heating Temperature and Fat Content on The Structure Development of Set Yogurt. J. Food Eng., 85(4):590-597.

Yoshida, Sh., 1990. Isolation of lactoglobulin an lactalbumun by Gel Filtration Using Sephacryl S-200 and Purification by Diethylaminoethyl Ion-Exchange Chromatography. J. Dai. Sci., 73:2292-2298. 